\title{
Growth and yield difference due to application of various levels of gibberelic acid in local and BARI falon-1
}

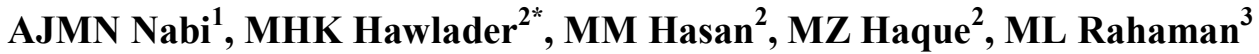 \\ ${ }^{1}$ Accelareting Agricultural Productivity Improvement, International Fertilizer Development Center, Bangladesh, \\ ${ }^{2}$ Department of Agricultural Botany, ${ }^{3}$ Office of the controller of examinations, Patuakhali Science and Technology \\ University, Dumki, Patuakhali-8602, Bangladesh
}

\begin{abstract}
An experiment was carried out at the research farm of Patuakhali Science and Technology University (PSTU) during the period from November 2010 to April 2011 to study on growth and yield performance of cowpea (BARI Falon-1 and local Falon) with different concentration of $\mathrm{GA}_{3}$ (control, 25.00, 33.33, 50.00 and $100.00 \mathrm{ppm}$ ) to find out the suitable variety and optimum level of gibberelic acid $\left(\mathrm{GA}_{3}\right)$ application which would be also suitable to cultivate under coastal region of Patuakhali. Among the treatments, $\mathrm{GA}_{3}$ at $33.33 \mathrm{ppm}$ treated plant of BARI Falon-1 showed the better performance on growth and yield contributing characters. As a result, the tallest plant $(62.53 \mathrm{~cm})$, number of leaves and branches plant ${ }^{-1}$ (28.67 and 20.07, respectively), TDM (83.99 g), CGR (1.68 $\mathrm{cm}^{2}$ day $\left.{ }^{-1}\right)$, RGR $\left(0.729 \mathrm{~cm}^{2}\right.$ day $\left.{ }^{-1}\right)$ and NAR $\left(1.275 \mathrm{~cm}^{2}\right.$ day $\left.{ }^{-1}\right)$ were exhibited from the variety BARI Falon-1 with the spraying of $\mathrm{GA}_{3}$ at $33.33 \mathrm{ppm}$ at harvest. Yield contributing characters had also higher such as pods plant ${ }^{-1}$ (11.67), length of pod $(17.20 \mathrm{~cm})$, seeds pod ${ }^{-1}(16.80), 100$-seed weight (12.49 g), seed yield (20.16 $\mathrm{g} \mathrm{plant}^{-1}$ and $\left.3139.93 \mathrm{~kg} \mathrm{ha}^{-1}\right)$ and harvest index $(24.04 \%)$ with the variety BARI Falon-1 whily it was treated by $33.33 \mathrm{ppm}$ $\mathrm{GA}_{3}$. Hence, it can be concluded that the application of $\mathrm{GA}_{3}$ up to $33.33 \mathrm{ppm}$ than other $\mathrm{GA}_{3}$ levels and BARI Falon-1 than Local Falon would be the most suitable for obtaining the greater yield of cowpea under the coastal area of Patuakhali region. So, considering the above observation, BARI Falon-1 therefore is suggested to cultivate in Patuakhali region while 33.33 ppm $\mathrm{GA}_{3}$ would be also optimum level for the better prodcution of cowpea.
\end{abstract}

Key words: Growth, yield difference, gibberelic acid, BARI falon-1

Progressive Agriculturists. All rights reserve

*Corresponding Author: howladercbt@yahoo.com

\section{Introduction}

Cowpea (Vigna unguiculata L, Walp.) is locally known as Falon which was grown as a grain legume crop in rabi season and fodder in kharif season in the tropics and sub-tropics covering Asia, Africa, Southern Europe, Southern United States and Central and South America (Ullah et al., 1995). Cowpea is probably of American origin from the fact that the plant was an important source of hay for cows in the United States and first found in literature in 1978. It was also called as "pease" and later "corn field pease", because of planting it between the rows of field corn. It is now called as "Southernpeas", "Blackeyed peas", "Field peas", "Pinkeyes", and "Crowders" etc. Cowpea is a hardy crop well adapted to relatively dry environments. In Bangladesh, the area under cowpea production is about 16 thousand hectares where the yield is $632 \mathrm{Kg}$ $\mathrm{ha}^{-1}$ and the production quantity 6000 tons (BBS, 2010). Cowpea fodder is an excellent source of essential nutrients with an average digestibility coefficient of $74.35 \%$ of the whole plant, $78.06 \%$ of crude protein, 72.42 of crude fiber, $76.98 \%$ of nitrogen free extract (soluble carbohydrate) and $71.81 \%$ of ether extract. The green pod of cowpea contains 51.40 $\%$ water, $22.5 \%$ protein, $10.1 \%$ crude fiber, $56.29 \%$ 
soluble carbohydrate, $2.10 \%$ fat and $9.0 \%$ minerals (Rahman et al., 1992). In Bangladesh, the number of livestock is decreasing due to the lack of green grasses in grazing fields. Recently the dairy farms surrounding the urban areas have increased due to the growing need of milk and milk products for the urban people. So to sustain the dairy industries it is essential to increase fodder production where cowpea could be a potential crop. The poor yield is attributed to unavailability of high yielding and stable genotypes along with appropriate advance agronomic practices. However, growth regulators especially auxins have been reported to enhance the vegetative growth of many crops including legumes (Roy et al., 1990). Application of growth regulators like auxin has been reported to enhance the vegetative growth of legumes (Roy et al., 1990; Jain et al., 1995; Singh and Sharma, 1996; Rao and Narayanan, 1998). For normal growth and development, gibberellic acid $\left(\mathrm{GA}_{3}\right)$ is a phytohormone that is needed in small quantities at low concentration to accelerate plant growth and development. $\mathrm{GA}_{3}$ enhances growth activities to plant, stimulates stem elongation and increases dry weight and yield (Deotale et al., 1998). The challenge is to find ways of improving cowpea productivity, where varietal improvement modified cropping systems and use of plant growth regulators (PGRs) any improve cowpea yield (Emongor, 2007). Moreover growth regulators are used in appropriate concentrations, these substances influence the plant architecture in a typical fashion and improve the yield potential. Therefore, the current research work undertaken to evaluate the effect of various concentrations of $\mathrm{GA}_{3}$ on growth and yield of Cowpea and to find out the most appropriate doses of $\mathrm{GA}_{3}$.

\section{Materials and Methods}

A field experiment was conducted at the research farm of Patuakhali Science and Technology University (PSTU), Patuakhali during the period from November 2010 to April 2011. Geographically, the research farm is located at $22^{0} 37^{\prime} \mathrm{N}$ latitude and $89^{\circ} 10^{\prime} \mathrm{E}$ longitudes. The area is named as Gangetic Tidal Floodplains and falls under Agroecological Zone "AEZ- 13". The area lies at 1.5 meter above mean sea level. The soil of the experimental field was silty caly loam having $\mathrm{pH}$ value of 7.00 . The OM content found $1.53 \%$ in most cases.
Deficiency of nitrogen is acute and widespread. Status of exchangeable potasium is almost satisfactory. Phosphorus, sulphur and other characterstics of soil status are also optimum for its cultivation. Climatic conditions are also favourable for its cultivation. Two varieties of cowpea such as BARI Falon-1 and Local Falon as planting materials and five different levels of Gibberelic Acid $\left(\mathrm{GA}_{3}\right)$ including control (without $\mathrm{GA}_{3}$ ) as treatment viz. $\mathrm{T}_{0}=$ Control (without $\mathrm{GA}_{3}$ ), $\mathrm{T}_{1}=25$ ppm, $\mathrm{T}_{2}=33.33 \mathrm{ppm}$ (recommended dose by Yon Longping high-tech. Agriculture Company Ltd.), $\mathrm{T}_{3}=$ $50 \mathrm{ppm}$ and $\mathrm{T}_{4}=100 \mathrm{ppm}$ were used for the present study. A 100 ppm solution of $\mathrm{GA}_{3}$ was prepared by dissolving $100 \mathrm{mg}$ of $\mathrm{GA}_{3}$ in $1 \mathrm{~L}$ of distilled water. The distilled water was added to make the volume 1 liter to get $100 \mathrm{ppm}$ solution which was used as treatment $\mathrm{T}_{4}$. Similarly another volume $\left(T_{1}, T_{2}\right.$ and $\left.T_{3}\right)$ of $G_{3}$ was prepared. Two factors experiment was laid out in a Randomized Complete Block Design (RCBD) with three replications. The size of each unit plot was $2.0 \mathrm{~m}$ $\times 2.0 \mathrm{~m}$ where line to line and seed to seed distances were 30 and $15 \mathrm{~cm}$, respectively, in each plot. The land of the experimental site was first opened on December 20, 2010 with a tractor and then the land was ploughed and cross-ploughed to obtain good tilth. All the weeds and stubbles were removed from the experimental field. The soil was treated with insecticides at the time of final ploughing. Insecticides Furadan $5 \mathrm{G}$ was used (a) $8 \mathrm{~kg} \mathrm{ha}^{-1}$ to protect young plants from the attack of mole cricket, ants, and cutworms. Fertilizers such as urea@8kg, TSP@6g and MoP20 g were applied for each plot during final plot preparation. The seeds of Falon (cowpea) were sown in the research field on January 3, 2011. The distances between row to row and seed to seeds were 40 and $15 \mathrm{~cm}$, respectively. Matured and viable 2 seeds were placed in each hole at $2-3 \mathrm{~cm}$ depth from the soil surface. Thinning out, gap filling, weeding, irrigation and disease and pest management operation were also done as intercultural operation for maximizing the yield. Continuous monitoring of growing seedlings and $\mathrm{GA}_{3}$ spraying was also done as per treatment. The first crop sampling was done on 30 days after sowing (DAS) and it was continued up to physiological maturity on 90 DAS at an interval of 30 days. Harvesting of the cowpea was done after 110 days of sowing. Data were collected when the foliage turned pale yellow. Data were recorded for 5 individual 
plants per plots in each replication. Yield data were also collected after harvest. The plants were separated into leaf, stem and roots and then their dry weight were recorded after drying them in an oven at $80 \pm 2^{\circ} \mathrm{C}$ for 72 hours. The data obtained from the experiment on various parameters were statistically analyzed by MSTAT-C computer program and the mean were adjusted by DMRT where at $5 \%$ levels of probability.

\section{Results and Discussion}

\section{Morphological Characters}

\section{Plant height}

Effect of genotypes and $\mathrm{GA}_{3}$ showed significant variation in respect of plant height at different days after sowing. The tallest plant (17.63 and 45.97 and $62.53 \mathrm{~cm}$ ) was obtained from the variety BARI Falon1 in 33.33 ppm $\mathrm{GA}_{3}$ followed by the local Falon in similar treatment at 30 and 60 DAS (16.87 and 44.70 $\mathrm{cm})$ and BARI Falon-1 in control treatment at 90 DAS $(59.77 \mathrm{~cm})$. Likewise, the shortest plant (13.60, 32.87 and $54.63 \mathrm{~cm}$ ) was found from the variety local Falon while it was treated by $100 \mathrm{ppm}$ at 30,60 and 90 DAS, respectively (Table 1). From the above observation, it was found that the plant height was increased accordingly with the advancement of the study. Beside, plant height also increase with the application of $\mathrm{GA}_{3}$ up to $33.33 \mathrm{ppm}$ after that it decreased at all the data recording stages.

\section{Leaves plant ${ }^{-1}$}

Effect of cowpea varieties and different levels of $\mathrm{GA}_{3}$ showed significant differences on leaves plant $^{-1}$ whereas the maximum leaves plant ${ }^{-1}(9.00,25.67$ and 28.67) was found from 33.33 ppm $\mathrm{GA}_{3}$ treated plant of BARI Falon-1 while similar $\mathrm{GA}_{3}$ treatments treated plant of Local Falon produced statistically identical higher production of leaves plant ${ }^{-1}$ at 60 and 90 DAS (25.33 and 28.33, respectively). On the other hand, the minimum leaves plant ${ }^{-1}$ (7.33) was recorded in both 50 and 100 ppm $\mathrm{GA}_{3}$ treated plant of BARI Falon-1 at 30 DAS while it was also the minimum in control treated plant of Local Falon at 60 DAS (20.33) and 100 ppm $\mathrm{GA}_{3}$ treated plant of Local Falon at 90 DAS (22.67) (Table 1). Omaima Mohamed et al. (2009) found that spraying snap bean plants with $25 \mathrm{ppm}$ vitamin B1 significantly increased number of leaf and branches, dry weight of shoots and total dry weight in both seasons.

\section{Branches plant ${ }^{-1}$}

A highly significant variation was found on branches plant $^{-1}$ to be the effect of two cowpea genotypes and different doses of $\mathrm{GA}_{3}$ (Table 1). The maximum branches plant ${ }^{-1}(4.73,9.67$ and 20.07) was found from the variety BARI Falon-1 in $\mathrm{GA}_{3}$ at $33.33 \mathrm{ppm}$ foliar spray and it was statistically similar to local Falon in both 33.33 and 50.00 ppm $\mathrm{GA}_{3}$ at 60 DAS (9.67 and 8.67, respectively) and $50 \mathrm{ppm} \mathrm{GA}_{3}$ at 90 DAS (19.40). On the other hand, BARI Falon-1 treated by $100 \mathrm{ppm} \mathrm{GA}_{3}$ produced significantly the minimum branches plant ${ }^{-1}$ (3.33 and 5.83) at 30 and 60 DAS, respectively and control treated plant of Local Felon at 90 DAS (15.67) while statistically similar minimum branches plant ${ }^{-1}$ were taken from 100 ppm $\mathrm{GA}_{3}$ treated plant of Local Falon at 30 DAS (3.33), and $100 \mathrm{ppm}$ treated plant of both BARI Falon-1 and Local Falon at 90 DAS (15.83 and 15.90 , respectively).

\section{Leaf area (LA)}

Statistical analysis of the data showed that the leaf area was significantly affected by the effect of varieties and different levels of $\mathrm{GA}_{3}$ (Table 2). The higher LA (103.73 and $507.34 \mathrm{~cm}^{2}$ plant $^{-1}$ ) was found in 33.33 ppm $\mathrm{GA}_{3}$ with the variety BARI Falon-1 at 30 and 60 DAS while statistically similar higher LA $\left(100.34 \mathrm{~cm}^{2}\right.$ plant $\left.{ }^{-1}\right)$ was also found in similar $\mathrm{GA}_{3}$ treated plant of Local Falon at 30 DAS. At 90 DAS, the highest LA $\left(2598.45 \mathrm{~cm}^{2}\right.$ plant $\left.^{-1}\right)$ was found in 100 ppm $\mathrm{GA}_{3}$ treated plant of BARI Falon-1. Among other effect, Local Falon showed the lowest LA in 100 ppm $\mathrm{GA}_{3}$ at $30 \mathrm{DAS}$ and without $\mathrm{GA}_{3}$ at 90 DAS $\left(80.35\right.$ and $1817.10 \mathrm{~cm}^{2}$ plant $^{-1}$, respectively) while $25 \mathrm{ppm} \mathrm{GA}_{3}$ treated plant of BARI Falon-1 showed the lower LA $\left(346.57 \mathrm{~cm}^{2}\right.$ plant $^{-1}$ ) and it was statistically identical to similar $\mathrm{GA}_{3}$ treated plant of Local Falon $\left(349.31 \mathrm{~cm}^{2}\right.$ plant $\left.^{-1}\right)$ at 60 DAS.

\section{Leaf area index (LAI)}

LAI showed significant difference due to the effect of varieties and $\mathrm{GA}_{3}$ levels at 60 and 90 DAS where 30 DAS did not vary significant (Table 2). At 60 DAS, 
the maximum LAI (1.153) was found with the variety BARI Falon-1 treated by 33.33 ppm $\mathrm{GA}_{3}$ and it was statistically similar to the similar $\mathrm{GA}_{3}$ treated plant of local Falon (1.113) while it was lower (0.903) in 0 ppm $\mathrm{GA}_{3}$ treated plant of Local Felon which was also statistically similar to $0,25.00$ and50.00 ppm treated plant of BARI Falon-1 (0.933, 0.930 and 0.913, respectively) and $100 \mathrm{ppm} \mathrm{GA}_{3}$ treated plant of Local Falon (0.943). $\mathrm{GA}_{3}$ at $33.33 \mathrm{ppm}$ treated plant of local Falon showed the higher LAI (1.133) at 90 DAS followed by similar $\mathrm{GA}_{3}$ treated plant of BARI Falon (1.060).

Table 1. Effect of varieties and different levels of $\mathrm{GA}_{3}$ on plant height, leaves plant ${ }^{-1}$ and branches plant ${ }^{-1}$ at different DAS

\begin{tabular}{|c|c|c|c|c|c|c|c|c|c|c|}
\hline \multirow{2}{*}{ Varieties } & \multirow{2}{*}{$\begin{array}{l}\mathrm{GA}_{3} \text { levels } \\
(\mathrm{ppm})\end{array}$} & \multicolumn{3}{|c|}{ Plant height (cm) } & \multicolumn{3}{|c|}{ Number of leaves plant $^{-1}$} & \multicolumn{3}{|c|}{ Number of branches plant $^{-1}$} \\
\hline & & $30 \mathrm{DAS}$ & 60 DAS & 90 DAS & $30 \mathrm{DAS}$ & 60 DAS & $90 \mathrm{DAS}$ & $30 \mathrm{DAS}$ & $60 \mathrm{DAS}$ & 90 DAS \\
\hline BARI & 0 (control) & $14.53^{\mathrm{d}}$ & $35.83^{\mathrm{cd}}$ & $59.77^{b}$ & $8.00^{\mathrm{abc}}$ & $21.33^{\mathrm{de}}$ & $24.00^{\mathrm{de}}$ & $3.67^{b c}$ & $6.50^{\mathrm{bc}}$ & $16.33^{\mathrm{d}}$ \\
\hline \multirow[t]{4}{*}{ Falon-1 } & 25 & $16.63^{b}$ & $37.43^{\mathrm{bcd}}$ & $58.80^{\mathrm{bc}}$ & $8.33^{\mathrm{abc}}$ & $23.33^{\mathrm{c}}$ & $25.67^{\mathrm{bc}}$ & $4.13^{\mathrm{abc}}$ & $7.33^{b}$ & $17.67^{\mathrm{bc}}$ \\
\hline & 33.33 & $17.63^{\mathrm{a}}$ & $45.97^{\mathrm{a}}$ & $62.53^{\mathrm{a}}$ & $9.00^{\mathrm{a}}$ & $25.67^{\mathrm{a}}$ & $28.67^{\mathrm{a}}$ & $4.73^{\mathrm{a}}$ & $9.67^{\mathrm{a}}$ & $20.07^{\mathrm{a}}$ \\
\hline & 50 & $16.50^{\mathrm{b}}$ & $40.50^{a b c}$ & $57.37^{\text {bcd }}$ & $7.33^{c}$ & $24.67^{\mathrm{ab}}$ & $26.33^{b}$ & $3.90^{\mathrm{abc}}$ & $7.33^{b}$ & $18.17^{\mathrm{b}}$ \\
\hline & 100 & $13.50^{\mathrm{e}}$ & $43.17^{\mathrm{ab}}$ & $55.50^{d}$ & $7.33^{c}$ & $21.67^{d}$ & $24.67^{\mathrm{cd}}$ & $3.33^{\mathrm{c}}$ & $6.83^{\mathrm{bc}}$ & $15.83^{\mathrm{d}}$ \\
\hline Local & 0 (control) & $13.53^{\mathrm{e}}$ & $31.50^{\mathrm{d}}$ & $56.60^{\mathrm{cd}}$ & $7.67^{\mathrm{bc}}$ & $20.33^{\mathrm{e}}$ & $23.00^{\mathrm{e}}$ & $3.67^{\mathrm{bc}}$ & $5.83^{c}$ & $15.67^{\mathrm{d}}$ \\
\hline \multirow[t]{4}{*}{ Falon } & 25 & $15.37^{\mathrm{c}}$ & $34.93^{\mathrm{cd}}$ & $59.63^{b}$ & $8.00^{a b c}$ & $21.67^{d}$ & $25.33^{\mathrm{bcd}}$ & $4.20^{\mathrm{ab}}$ & $7.50^{b}$ & $17.23^{\mathrm{c}}$ \\
\hline & 33.33 & $16.87^{\mathrm{b}}$ & $44.70^{\mathrm{a}}$ & $59.60^{b}$ & $8.67^{\mathrm{ab}}$ & $25.33^{\mathrm{a}}$ & $28.33^{a}$ & $4.47^{\mathrm{ab}}$ & $9.67^{\mathrm{a}}$ & $19.40^{\mathrm{a}}$ \\
\hline & 50 & $15.57^{\mathrm{c}}$ & $41.40^{\mathrm{abc}}$ & $55.57^{\mathrm{d}}$ & $7.67^{b c}$ & $23.67^{\mathrm{bc}}$ & $25.67^{b c}$ & $4.00^{\mathrm{abc}}$ & $8.67^{a}$ & $17.33^{\mathrm{bc}}$ \\
\hline & 100 & $13.60^{\mathrm{e}}$ & $32.87^{\mathrm{d}}$ & $54.63^{d}$ & $7.67^{b c}$ & $20.67^{\mathrm{de}}$ & $22.67^{\mathrm{e}}$ & $3.33^{c}$ & $6.67^{\mathrm{bc}}$ & $15.90^{\mathrm{d}}$ \\
\hline$\overline{C V}(\%)$ & & 2.52 & 9.46 & 2.70 & 8.47 & 2.96 & 3.05 & 11.22 & 8.08 & 2.82 \\
\hline $\operatorname{LSD}_{(0.05)}$ & & 0.6644 & 6.301 & 2.686 & 1.158 & 1.158 & 1.333 & 0.5556 & 1.053 & 0.8386 \\
\hline
\end{tabular}

Among other effects, the lower LAI (0.870) was found in $100 \mathrm{ppm} \mathrm{GA}_{3}$ treated plant of both BARI Falon-1 and local Falon which was also statistically identical to $0,25.00$ and $50.00 \mathrm{ppm} \mathrm{GA}_{3}$ treated plant of BARI Falon-1 (0.890, 0.943 and 0.880, respectively) and $25.00 \mathrm{ppm}$ treated plant of Local Felon (0.930) at 90 DAS.

\section{Total dry matter (TDM)}

Effect of varieties and $\mathrm{GA}_{3}$ also showed significant variation at 30,60 and 90 DAS on TDM where the higher TDM (2.90, 33.71 and 83.99 g plant $^{-1}$ ) was found in 33.33 ppm $\mathrm{GA}_{3}$ spraying plant of both BARI Falon-1 at 30, 60 and 90 DAS while local Falon-1 in similar foliar spray of $\mathrm{GA}_{3}$ showed statistically similar higher TDM at 30 DAS $(2.90 \mathrm{~g}$ plant $\left.^{-1}\right) . \mathrm{GA}_{3}$ at $100 \mathrm{ppm}$ showed the lowest TDM with both Local Falon at 30 DAS (2.74 g plant $\left.^{-1}\right)$ and BARI Falon at 90 DAS (54.95 g plant $^{-1}$ ) while without $\mathrm{GA}_{3}$ treated plant of Local Falon showed the lower TDM (24.26 and 62.) at 60 DAS (Table 2).

\section{Growth characters}

\section{Crop growth rate (CGR)}

The data on CGR revealed no significant differences at the stage between 30 to 60 DAS but significant at 60 to 90 DAS due to the effect of varieties and different doses of $\mathrm{GA}_{3}$. As a result, the maximum CGR (1.676 $\left.\mathrm{gm}^{-2} \mathrm{day}^{-1}\right)$ was recorded in 33.33 ppm $\mathrm{GA}_{3}$ treated plant of BARI Falon-1 which was statistically identical to 33.33 ppm $\mathrm{GA}_{3}$ treated plant of local Falon $\left(1.623 \mathrm{gm}^{-2}\right.$ day $\left.^{-1}\right)$. Likewise, the lowest CGR $\left(0.849 \mathrm{gm}^{-2}\right.$ day ${ }^{1}$ ) was found in $100 \mathrm{ppm} \mathrm{GA}_{3}$ treated plant of BARI Falon-1 (Figure 1).

\section{Relative growth rate (RGR)}

Effect of varieties and $\mathrm{GA}_{3}$ showed significant variation at both stages of RGR (Fig. 1). The foliar spray at 33.33 ppm $\mathrm{GA}_{3}$ treated plant of BARI Falon-1 gave the maximum RGR (0.447 and 0.729 $\mathrm{cm}^{2}$ day $^{-1}$ ) at both stages of 30 to 60 DAS and 60 to 90 DAS, respectively which was statistically similar to $50 \mathrm{ppm} \mathrm{GA}_{3}$ treated plant of BARI 
Falon- 1 at the stage between 30 to 60 DAS $(0.423$ $\mathrm{cm}^{2}$ day $\left.^{-1}\right)$. On the other hand, the minimum RGR was recorded in control treated plant of local Falon at 30 to $60 \mathrm{DAS}\left(0.310 \mathrm{~cm}^{2} \mathrm{day}^{-1}\right)$ and $50 \mathrm{ppm} \mathrm{GA}$ treated plant of BARI Falon-1 and control treated plant of Local Falon at 60 to 90 DAS (both similar $0.559 \mathrm{~cm}^{2}$ day $^{-1}$ ).

Table 2. Effect of varieties and different levels of $\mathrm{GA}_{3}$ on leaf area plant ${ }^{-1}$, Leaf area and dry matter weight at different DAS

\begin{tabular}{|c|c|c|c|c|c|c|c|c|c|c|}
\hline \multirow{2}{*}{ Varieties } & \multirow{2}{*}{$\begin{array}{l}\mathrm{GA}_{3} \text { levels } \\
(\mathrm{ppm})\end{array}$} & \multicolumn{3}{|c|}{ Leaf area per plant $\left(\mathrm{cm}^{2}\right.$ plant $\left.{ }^{-1}\right)$} & \multicolumn{3}{|c|}{ Leaf area index (LAI) } & \multicolumn{3}{|c|}{ Dry matter weight plant $^{-1}(\mathrm{~g})$} \\
\hline & & $30 \mathrm{DAS}$ & $60 \mathrm{DAS}$ & 90 DAS & $30 \mathrm{DAS}$ & 60 DAS & 90 DAS & $30 \mathrm{DAS}$ & $60 \mathrm{DAS}$ & 90 DAS \\
\hline BARI & 0 (control) & $89.263^{\mathrm{cd}}$ & $433.223^{\mathrm{cd}}$ & $2020.387^{\text {efg }}$ & 0.65 & $0.933^{b}$ & $0.890^{\mathrm{c}}$ & $2.80^{\mathrm{abc}}$ & $25.11^{\mathrm{ef}}$ & $65.77^{\mathrm{d}}$ \\
\hline \multirow[t]{4}{*}{ Falon-1 } & 25 & $81.703^{\mathrm{de}}$ & $346.573^{\mathrm{e}}$ & $2426.887^{\mathrm{ab}}$ & 0.66 & $0.930^{\mathrm{b}}$ & $0.943^{\mathrm{c}}$ & $2.83^{\mathrm{abc}}$ & $26.69^{d}$ & $70.91^{\mathrm{c}}$ \\
\hline & 33.33 & $103.733^{\mathrm{a}}$ & $507.340^{\mathrm{a}}$ & $2139.773^{\mathrm{def}}$ & 0.71 & $1.153^{\mathrm{a}}$ & $1.060^{\mathrm{ab}}$ & $2.90^{\mathrm{a}}$ & $33.71^{\mathrm{a}}$ & $83.99^{\mathrm{a}}$ \\
\hline & 50 & $92.977^{\mathrm{bc}}$ & $485.240^{\mathrm{ab}}$ & $2151.993^{\text {cde }}$ & 0.69 & $0.913^{\mathrm{b}}$ & $0.880^{\mathrm{c}}$ & $2.84^{\mathrm{abc}}$ & $32.01^{\mathrm{b}}$ & $70.57^{\mathrm{c}}$ \\
\hline & 100 & $82.080^{\text {de }}$ & $425.800^{\mathrm{cd}}$ & $2598.847^{\mathrm{a}}$ & 0.67 & $0.993^{a b}$ & $0.870^{\mathrm{c}}$ & $2.83^{a b c}$ & $29.48^{\mathrm{c}}$ & $54.95^{\mathrm{f}}$ \\
\hline Cocal & $0(\mathrm{co}$ & $85.967^{\text {cde }}$ & 396. & $1817.100^{\mathrm{g}}$ & 0.66 & $0.903^{\mathrm{b}}$ & & $2.85^{\mathrm{ab}}$ & & $62.85^{\mathrm{e}}$ \\
\hline \multirow[t]{4}{*}{ Falon } & 25 & $85.407^{\mathrm{de}}$ & $349.313^{\mathrm{e}}$ & $2411.910^{\mathrm{abc}}$ & 0.70 & $1.037^{\mathrm{ab}}$ & $0.930^{\mathrm{c}}$ & $2.77^{b c}$ & $25.78^{\mathrm{de}}$ & $69.67^{c}$ \\
\hline & 33.33 & $100.340^{\mathrm{a}}$ & $448.633^{b c}$ & $1962.060^{\text {efg }}$ & 0.70 & $1.113^{\mathrm{a}}$ & $1.133^{\mathrm{a}}$ & $2.90^{\mathrm{a}}$ & $31.22^{\mathrm{b}}$ & $79.90^{\mathrm{b}}$ \\
\hline & 50 & $96.767^{\mathrm{ab}}$ & $436.377^{\mathrm{cd}}$ & $1875.637^{\mathrm{fg}}$ & 0.71 & $0.987^{\mathrm{ab}}$ & $0.973^{b c}$ & $2.86^{\mathrm{ab}}$ & $29.66^{\mathrm{c}}$ & $69.21^{\mathrm{c}}$ \\
\hline & 100 & $80.347^{\mathrm{e}}$ & $388.767^{\mathrm{de}}$ & $2325.560^{\mathrm{bcd}}$ & 0.66 & $0.943^{\mathrm{b}}$ & $0.870^{\mathrm{c}}$ & $2.74^{\mathrm{c}}$ & $27.07^{\mathrm{d}}$ & $66.27^{d}$ \\
\hline$\overline{C V}(\%)$ & & 2.346 & 4.730 & 84. & 3.07 & 5.00 & 3.89 & 2.04 & 2.78 & 2.34 \\
\hline $\mathrm{SD}_{(0.05)}$ & & 969 & 14.75 & 250.70 & NS & 0.1534 & 0.1085 & 0.09396 & 1.357 & 2.789 \\
\hline
\end{tabular}

\section{Net assimilation rate (NAR)}

NAR was significantly affected by the effect of cowpea varieties and different levels of $\mathrm{GA}_{3}$ at 60 to 90 DAS but a non significant variation was found at 30 to 60 DAS (Fig. 1). At 60 to 90 DAS, 33.33 ppm $\mathrm{GA}_{3}$ treated plant of BARI Falon-1 gave the maximum NAR (1.275) and $100 \mathrm{ppm} \mathrm{GA}_{3}$ treated plant of BARI Falon-1 sowed the minimum NAR (0.708).
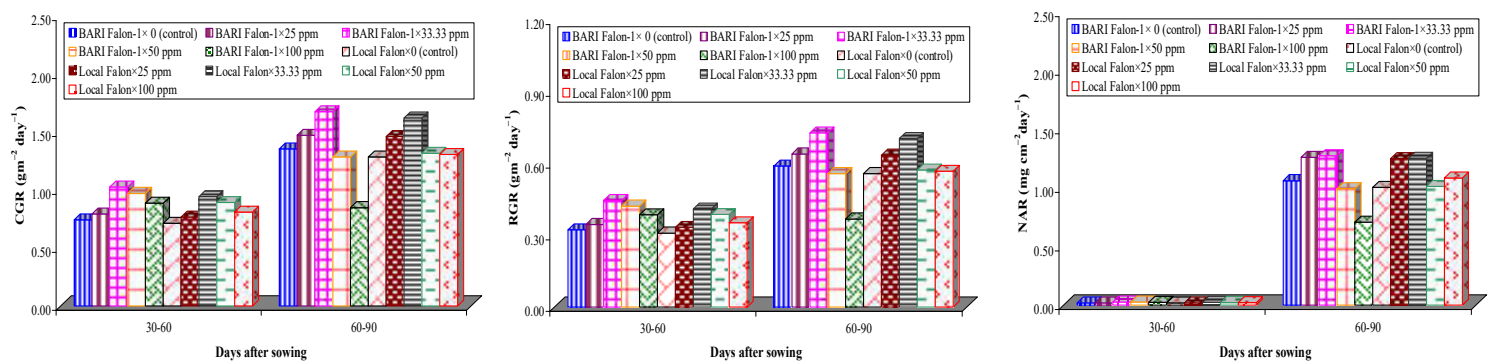

Figure 1. Effect of $\mathrm{GA}_{3}$ on CGR (A), RGR (B) and NAR (C) at different growth stages

\section{Yield Parameters}

Seeds pod $^{-1}$

Performance of cowpea varieties and $\mathrm{GA}_{3}$ on seeds $\operatorname{pod}^{-1}$ showed significant variation (Table 3). Foliar application of $\mathrm{GA}_{3}$ at $33.33 \mathrm{ppm}$ gave the maximum seeds $\operatorname{pod}^{-1}$ (16.80) with the variety BARI Falon-1 which was closely followed by local
Falon (15.67) in similar $\mathrm{GA}_{3}$ levels. Likewise, minimum seeds $\operatorname{pod}^{-1}$ (11.17) was noticed in 100 ppm $\mathrm{GA}_{3}$ treated plant of local Falon.

\section{Pods plant ${ }^{-1}$}

Pods plant ${ }^{-1}$ had also significant due to the effect of varieties and different doses of $\mathrm{GA}_{3}$ where pods plant $^{-1}$ varied from 7.67 to 11.67 . The maximum 
pods plant ${ }^{-1}$ (11.67) was found in 33.33 ppm $\mathrm{GA}_{3}$ treated plant of BARI Falon-1 and it was statistically similar to similar $\mathrm{GA}_{3}$ treated plant of local Falon (11.33). $\mathrm{GA}_{3}$ foliar spray at $100 \mathrm{ppm}$ gave the minimum pods plant $^{-1}$ (7.67) with both BARI Falon-1 and local Falon.

\section{Length of pod}

A highly significant variation was recorded due to the effect of cowpea varieties and different levels of $\mathrm{GA}_{3}$. The longest pod $(17.20 \mathrm{~cm})$ was found in 33.33 ppm $\mathrm{GA}_{3}$ treated plant of BARI Falon-1 which was statistically similar to $\mathrm{GA}_{3}$ treated plant of local Falon $(16.90 \mathrm{~cm})$. On the other hand, the shortest pod $(13.20 \mathrm{~cm})$ was found in $100 \mathrm{ppm} \mathrm{GA}$ treated plant of local Falon (Table 3).

\section{Hundred-seed weight}

Effect of varieties and $\mathrm{GA}_{3}$ on 100 -seeds weight showed significant variation where foliar application of $\mathrm{GA}_{3}$ at $33.33 \mathrm{ppm}$ gave the highest 100 -seeds weight (12.49 g) regarding BARI Falon1 which was closely followed by the local Falon treated by the similar $\mathrm{GA}_{3}$ (12.02 g). Likewise, the lowest 100 -seed $(10.37 \mathrm{~g})$ was observed in 100 ppm $\mathrm{GA}_{3}$ treated plant of local Falon (Table 3).

\section{Seed yield}

Responses of varieties and $\mathrm{GA}_{3}$ had significant on seeds yield (Table 3). Foliar application of $\mathrm{GA}_{3}$ at 33.33 ppm on BARI Falon-1 gave the higher yield (20.16 $\mathrm{g} \mathrm{plant}^{-1}$ or $3139.93 \mathrm{~kg} \mathrm{ha}^{-1}$ ) which was statistically differed from other effect. On the other hand, the lowest seeds yield (11.52 $\mathrm{g} \mathrm{plant}^{-1}$ or $1936.57 \mathrm{~kg} \mathrm{ha}^{-1}$ ) was noticed in $100 \mathrm{ppm} \mathrm{GA}_{3}$ treated plant of local Falon where the same variety also showed statistically similar seed yield (11.63 g plant $^{-1}$ or $1959.67 \mathrm{~kg} \mathrm{ha}^{-1}$ ) in control treatment. Reddy (2002) also observed seed yield increased significantly with application of NAA 40 and 60 ppm followed by Lihocin (500 ppm) compared to control. Swaminathan et al. (2007) recommended that, application of panchagavya at 3 per cent as foliar spray on 15, 25 and 40 DAS recorded significantly highest seed yield (1195 kg /ha) in black gram.

Table 3. Effect of different levels of $\mathrm{GA}_{3}$ on yield and yield contributing characters at harvest

\begin{tabular}{|c|c|c|c|c|c|c|c|c|}
\hline Varieties & $\begin{array}{l}\mathrm{GA}_{3} \text { levels } \\
(\mathrm{ppm})\end{array}$ & Pods plant ${ }^{-1}$ & $\begin{array}{l}\text { Pod length } \\
\text { (cm) }\end{array}$ & $\begin{array}{l}\text { Seeds } \\
\operatorname{pod}^{-1}\end{array}$ & $\begin{array}{l}\text { 100- seed } \\
\text { weight }(\mathrm{g})\end{array}$ & $\begin{array}{l}\text { Seed yield } \\
\text { plant }^{-1}(\mathrm{~g})\end{array}$ & $\begin{array}{l}\text { Seed yield } \\
\left(\mathrm{kg} \mathrm{ha}^{-1}\right)\end{array}$ & $\begin{array}{l}\text { Harvest } \\
\text { index }(\%)\end{array}$ \\
\hline \multirow[t]{5}{*}{ BARI Felon-1 } & 0 (control) & $8.333^{\mathrm{def}}$ & $14.767^{\mathrm{cd}}$ & $14.43^{d}$ & $10.877^{\mathrm{de}} \mathrm{f}$ & $12.443^{\mathrm{ef}}$ & $2014.533^{\text {ef }}$ & $18.947^{b c}$ \\
\hline & 25 & $9.667^{\text {cde }}$ & $15.467^{b}$ & $15.00^{c}$ & $11.233^{\mathrm{cde}}$ & $13.523^{d}$ & $2221.700^{\mathrm{d}}$ & $19.077^{\mathrm{bc}}$ \\
\hline & 33.33 & $11.667^{\mathrm{ab}}$ & $17.200^{\mathrm{a}}$ & $16.80^{\mathrm{a}}$ & $12.490^{\mathrm{a}}$ & $20.157^{\mathrm{a}}$ & $3139.933^{\mathrm{a}}$ & $24.010^{\mathrm{a}}$ \\
\hline & 50 & $10.000^{\mathrm{ab}}$ & $15.400^{b}$ & $14.73^{\mathrm{cd}}$ & $11.607^{b c}$ & $16.350^{b}$ & $2668.500^{b}$ & $23.177^{\mathrm{a}}$ \\
\hline & 100 & $7.667^{\mathrm{f}}$ & $14.333^{d}$ & $12.73^{\mathrm{f}}$ & $10.890^{\mathrm{def}}$ & $13.123^{\mathrm{de}}$ & $2187.133^{\mathrm{de}}$ & $23.943^{\mathrm{a}}$ \\
\hline \multirow[t]{5}{*}{ Local Felon } & 0 (control) & $8.333^{\text {def }}$ & $13.467^{\mathrm{cd}}$ & $13.97^{\mathrm{e}}$ & $10.763^{\text {ef }}$ & $11.633^{f}$ & $1959.967^{\mathrm{f}}$ & $18.573^{c}$ \\
\hline & 25 & $9.667^{\mathrm{bcd}}$ & $14.267^{b}$ & $13.67^{\mathrm{e}}$ & $11.420^{\mathrm{bcd}}$ & $13.033^{\mathrm{de}}$ & $2198.300^{\mathrm{de}}$ & $18.710^{\mathrm{c}}$ \\
\hline & 33.33 & $11.333^{\mathrm{a}}$ & $16.900^{\mathrm{a}}$ & $15.67^{\mathrm{b}}$ & $12.017^{\mathrm{ab}}$ & $16.990^{b}$ & $2833.500^{b}$ & $20.890^{b}$ \\
\hline & 50 & $9.000^{\mathrm{abc}}$ & $15.167^{\mathrm{c}}$ & $13.80^{\mathrm{e}}$ & $11.633^{b c}$ & $14.537^{c}$ & $2422.700^{c}$ & $20.963^{b}$ \\
\hline & 100 & $7.667^{\mathrm{f}}$ & $13.200^{\mathrm{de}}$ & $11.17^{\mathrm{g}}$ & $10.367^{f}$ & $11.517^{\mathrm{f}}$ & $1936.567^{\mathrm{f}}$ & $17.140^{c}$ \\
\hline$\overline{C V(\%)}$ & CV (\%) & 7.17 & 3.50 & & 3.05 & 4.01 & 5.24 & 5.63 \\
\hline $\operatorname{LSD}_{(0.05)}$ & $\operatorname{LSD}_{(0.05)}$ & 1.148 & 0.9012 & & 0.5942 & 0.9854 & 190.20 & 1.982 \\
\hline
\end{tabular}

\section{Harvest index (HI)}

Effect of varieties and $\mathrm{GA}_{3}$ levels found to be significant in respect of $\mathrm{HI}$ where the maximum $\mathrm{HI}$ $(24.01 \%)$ was found in the foliar spray treatment of $\mathrm{GA}_{3}$ at $33.33 \mathrm{ppm}$ when the variety was BARI
Falon-1 which was also statistically similar to similar variety in 50 and 100 ppm $\mathrm{GA}_{3}$ (23.18 and $23.94 \%$, respectively). On the other hand, the lowest $\mathrm{HI}(17.14 \%)$ was found in $100 \mathrm{ppm} \mathrm{GA}_{3}$ and it was also statistically similar with the similar variety in 
control and 25 ppm $\mathrm{GA}_{3}$ (18.57 and 18.71\%, respectively).

\section{Conclusion}

In view of the above results (all morphological parameters, yield and yield contributing parameters) and discussion, it was concluded that BARI Falon-1 than Local Falon and foliar spray of $\mathrm{GA}_{3}$ at $33.33 \mathrm{ppm}$ than other levels showed better response on growth and yield attributing characters. Considering the overall performance, it could be also suggested that the variety BARI Falon-1 is more suitable than Local Falon and 33.33 ppm $\mathrm{GA}_{3}$ than other levels to cultivate in coastal areas of Patuakhali region for getting the higher yield of cowpea.

\section{References}

BBS (Bangladesh Bureau of Statistics). (2010). Statistical Year Book of Bangladesh. BBS Div. Min. Plan., Govt. Peoples Repub. Bangladesh, p. 37.

Castro, PRC, ES Evangelista, E Melotto, E Rodrigues (1989). Action of growth regulators on rape (Brassica napus L.). Revista Decreasing Agriculture (Piracicaba) 64(1): 3544. [Cited from Plant Growth Regulator Abst., 1990. 16 (3): 65].

Deotale, RD, VG Mask, NV Sorte, BS Chimurkar, AZ Yerne (1998). Effect of $\mathrm{GA}_{3}$ and IAA on morpho-physiological parameters of soybean. J. Soils \& Crops., 8(1): 91-94. [Cited from Field Crop Abst. 1998. 51(11): 1114].

Emongor, VE (2007). Gibberellic acid $\left(\mathrm{GA}_{3}\right)$ influence on vegetative growth, nodulation fand yield of Cowpea (Vigna unguiculata L. Walp.). J. Agron., 6(4): 509-517.

Jain, PC, A Chandra, AK Naidu, JP Taiwari (1995). Influence of N and NAA on growth and yield parameters of cowpea (Vigna unguiculata (L) Walp.) during summer. JNKVV Res. J., 27(1): 49-52.
Hoque, MM, MS Haque (2002). Effects of GA and its mode of application on morphology and yield parameters of mungbean (Vigna radiate L.). Pak J. Biol. Sci., 5(3): 281-283.

Islam, MK, ASM Islam, M Harun-or-Rashid (2006). Effect of biofertilizer and plant growth regulators on growth of summer mungbean. Intl. J. Bot., 2(1): 36-41.

Rahman, MM, MR Islam, M Islam (1992). Biomass yield, chemical composition and nutritive value of cowpea (Vigna unguiculata L. (Walp.)) for goats. Bangladesh J. Animal Sci., 21(1-2): 1-4.

Rao, JSP, A Narayanan (1998). Effect of water and light stress and foliar application of auxin on flower abscission and seed yield of pigeon pea. Field crop Abst. P. 5191.

Roy, SK, AK Roy, PK Biswas, AFMM Zaman (1990). Effect of mixtalol on dry matter production and yield of cowpea. Bangladesh Agron. J., 3(1\&2): 15-19.

Singh, DB, TVRS Sharma (1996). Effect of $\mathrm{GA}_{3}$, NAA and 2,4-D on growth and yield of cowpea variety Arka Garima. Flora and Fauna (Jhansi). 2(1): 5-6.

Srikant, SP (2003). Influence of mother plant nutrition and growth regulators on crop growth, seed yield and quality in clusterbean. M.Sc. (Agri.) Thesis, Univ. of Agric. Sci., Dharwad, Karnataka (India).

Ullah, MJ, AMMD Rahman, MH Ali (1995). Effect of sowing date on cowpea (Vigna unguiculata). Indian J. Agron., 40(4): 713-714.

Upadhayay, RG (2002). Response of growth regulators on flower drop, fruit setting, biochemical constituents and yield of chickpea (Cicer arietinum L.) under mid hill conditions of Himachal Pradesh. Legume Res., 25(3): 211-214.

Zaky, MH, OR El-Zeiny, ME Ahmed (2006). Effects of humic acid on growth and productivity of bean plants grown under plastic low tunnels and open field. Egypt. J. Appl. Sci., 21(4): 582-596. 